\title{
The role of estradiol in the immune response against COVID-19
}

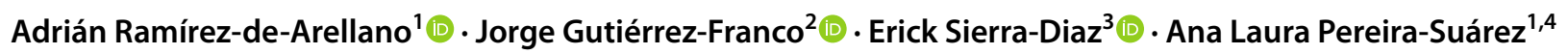

Received: 2 February 2021 / Accepted: 11 May 2021 / Published online: 17 June 2021

(c) Hellenic Endocrine Society 2021

\begin{abstract}
Severe acute respiratory syndrome coronavirus-2 (SARS-CoV-2) is the pathogen agent causing coronavirus disease (COVID)19 , which was declared a global pandemic in 2020. The spike protein of this virus and the angiotensin-converter enzyme (ACE)-2 in host cells in humans play a vital role in infection and in COVID-19 pathogenesis. Estradiol is known to modulate the actions of immune cells, and, therefore, the antiviral mechanisms of these cells could also be modified by this hormone stimulus. Even though estradiol is not considered a protective factor, evidence shows that women with high levels of this hormone have a lower risk of developing severe symptoms and an even a lower incidence of death. Understanding the mechanism of action of estradiol with regard to viral infections and COVID-19 is essential for the improvement of therapeutic strategies. This review aims to describe the effects that estradiol exerts on immune cells during viral infections and COVID-19.
\end{abstract}

Keywords COVID-19 · Estradiol $\cdot$ Immune response $\cdot$ SARS-CoV-2 $\cdot$ Progesterone

\section{Background}

Severe acute respiratory syndrome coronavirus-2 (SARSCoV-2), the pathogen agent causing coronavirus disease (COVID)-19, is thought to have originated in Wuhan, China, and has caused the current global pandemic which is a major public health issue. SARS-CoV-2 is a single-stranded RNA virus of $50-200 \mathrm{~nm}$ in diameter that presents a pulmonary tissue tropism. It belongs to the family Coronaviridae and

Ana Laura Pereira-Suárez

analauraps@hotmail.com

1 Instituto de Investigación en Ciencias Biomédicas, Centro Universitario de Ciencias de La Salud, Universidad de Guadalajara, Guadalajara, Jalisco 44 340, México

2 Unidad Académica de Ciencias Químico Biológicas Y Farmacéuticas, Universidad Autónoma de Nayarit, Tepic, Nayarit 63 000, México

3 Departamento de Salud Pública, Centro Universitario de Ciencias de La Salud, Universidad de Guadalajara, División de Epidemiología, Unidad Medica de Alta Especialidad, Hospital de Especialidades, Centro Médico Nacional de Occidente, Guadalajara, Jalisco 44340, México

4 Departamento de Microbiología Y Patología, Centro Universitario de Ciencias de La Salud, Universidad de Guadalajara, Sierra Mojada \# 950, Colonia Independencia, CP, 44340 Guadalajara, Jalisco, México expresses four structural proteins, namely, spike (S), envelope (E), membrane (M), and nucleocapsid (N) proteins [1].

The $\mathrm{S}$ protein has a high affinity for the angiotensin-converter enzyme (ACE)-2, and this is precisely what determines the cellular tropism of the virus. Because ACE-2 is highly expressed in the lung, heart, ileum, and kidney cells, these organs are more affected than others, and it explains the heterogeneous symptomatology observed in patients $[1,2]$.

Some patients suffer from a mild case of the disease with light or mild symptoms. However, others can develop a series of medical conditions, including pneumonia, myocarditis, hypercoagulability, and liver and kidney injury. In some severe cases, heart failure, multiorgan failure, septic shock, and even death can occur [3].

Even though the incidence of COVID-19 seems to be similar in both genders, men are at a higher risk of a worse outcome or death, with the odds up to 2.4 times higher than those for women. According to information from Global Health $50 / 50$, there is a $2: 1$ ratio worldwide when analyzing how rapidly the infection progresses and the severity of symptoms when comparing males with females [4].

Some studies of pregnant women infected with SARSCoV-2 show that they did not clinically evolve to a more severe condition and outcome, as shown in the following two reports. One study reported that nine women diagnosed with COVID-19 in the third trimester developed pneumonia, but none needed mechanical ventilation or died [5]. 
According to another study, pregnant women with COVID19 do not have a higher risk of developing severe symptoms like pneumonia as compared to non-pregnant women [6]. Even though pregnancy cannot be considered a protective factor, female hormones could play a protective role against SARS-CoV-2 infection at different levels, which is the main focus of this review. The present review aims to analyze the mechanisms modulated by estradiol that may lead to SARSCoV-2 infection.

\section{COVID-19 and immune response}

Many questions are still to be resolved regarding the immune response to SARS-CoV-2 However, even though the precise mechanisms of innate immunity are yet to be described, it is known that cells and molecules belonging to this type of immunity play a crucial role in the outcome of COVID-19.

Mucosal surfaces are one of the first barriers that SARS$\mathrm{CoV}-2$ encounters on entering the body, mainly via the respiratory tract. $\operatorname{IgA}$, which is present on the oral mucosa and conjunctival epithelium, may aid in protecting against the infection [7]; it has, however, been observed to increase in severe cases of SARS-CoV-2 infections [8]. Moreover, the response induced by IgA in COVID-19 was observed in 75\% of the patients during the first week of infection, and was even higher and more persistent than an IgM response [7]. As for IgG, they are present in $79.8 \%$ of patients and may appear even earlier than or else at the same time as IgM. Lastly, IgM and IgG titers were higher in severe COVID-19 patients than in those with mild symptoms [9].

An increase in monocytes has been reported in severe COVID-19 cases. Moreover, the high neutrophil-to-lymphocyte ratio has been associated with a bad prognosis [10]. Macrophages are an essential cellular component of the immune system, and they have been found to heavily infiltrate the bronchial area. SARS-CoV-2-infected macrophages that express ACE2 with increasing IL-6 levels have been observed, which contributes to typical inflammation in COVID-19, this ultimately leading to a cytokine storm [11]. The latter will be discussed later.

Monocytes and macrophages are the primary cells that coordinate an inflammatory response by activating NF-kB and IFN regulatory factor pathways [12]. In turn, type I IFNs are essential in activating NK cells, which are reduced and anergic in COVID-19 patients [13]. In addition, RNA in SARS-CoV-2 is recognized by intracellular TLRs activating the production of type I IFNs and other inflammatory molecules such as p38MAPK and AP-1 [14].

As for NK cells, evidence shows that their count is lower in COVID patients than in healthy subjects, and they present an exhausted and more inflammatory profile after SARSCoV-2 infection [13]. High expression of NKG2A has been reported in NK cells during COVID-19, which prevents the expression of IFN $\gamma$, IL-2, and TNF $\alpha$, and reduces the levels of granzyme B. Tim-3 is expressed in NK cells during COVID-19, and has been proven to be associated with decreased cytotoxicity [15]. The pulmonary microenvironment is surrounded by chemokines, such as MCP-1 and IP-10, which attract NK cells, and cytokines, like IL-6 and IL-10, that are known for reducing the cytotoxicity of NK cells [16].

Dendritic cells (DC) represent a bridge between innate and adaptative immunity because they are professional antigen-presenting cells that activate lymphocytes against SARS-CoV-2. Some studies have concluded that circulating $\mathrm{CD} 1 \mathrm{c}^{+}, \mathrm{CD}_{14} 1^{+}$, and plasmacytoid DC subpopulations are diminished, which impairs their activity; however, $\mathrm{CD} 1 \mathrm{c}+\mathrm{DC}$ cells are accumulated in the lung [17]. Moreover, plasmacytoid DC are IFN producers, and because the ratio of classical DC/plasmacytoid DC is increased in severe acute COVID-19 patients, this could explain the inadequate protection mounted against the infection in these patients [18]. There is no information as yet about antigen processing and presentation by DCs in COVID-19. However, in SARS$\mathrm{CoV}-1$, which is the closest infection model in humans, infected DCs are prevented from achieving maturation since they cannot perform an antigen presentation [19].

Because hormones modulate the maturation of these immune cells, it is vital to understand the effect that estrogen exerts on them because it could help us understand the different outcomes observed in males and females during COVID-19.

Cytokine storm has been reported in patients with severe symptoms: it is associated with a poor clinical outcome [20] and consists in the excessive production of IL- $1 \beta$, IL-2, IL-6, IL-8, and TNF- $\alpha[10,21]$, which leads to macrophage activation in acute exacerbation [21]. As the disease advances, the proinflammatory cytokine that is produced increases. Elevation of IL- 6 and the macrophage activation syndrome might explain the appearance of $\mathrm{C}$-reactive protein, which is usually not expressed in viral infections [22].

Regarding adaptative immunity, as in any other viral infection, it is presumed that SARS-CoV-2 leads to a Th1 type immune response [23].

In severe COVID-19 cases, $\mathrm{CD} 8^{+}, \mathrm{CD}^{+}$, and regulatory $\mathrm{T}$ cells decrease, which contrasts with patients with only mild symptomatology, where lymphocytic counts were higher [24]. However, in the abovementioned cases, lymphocyte counts were lower than in healthy donors [13]. CD8 ${ }^{+}$ T exhaustion phenotype is expressed with NKG2A, PD-1, and TIM-3. This finding correlates with the proinflammatory cytokine storm observed in COVID-19 [25]. SARS-CoV-2 can also induce lymphocyte apoptosis by increasing PD-1, which is upregulated during the late phase of the disease [26]. Moreover, naïve helper T cells increase in number, 
while the cytotoxic or suppressor $\mathrm{T}$ cells are diminished in severe COVID-19 [21]. Another mechanism used by SARS$\mathrm{CoV}-2$ to alter $\mathrm{T}$ cell function is the deregulation of class I and II MHC expression, which reduces antigen presentation [13].

A decrease in $\mathrm{B}$ cell frequencies has been reported during the COVID-19 pandemic. Humoral responses play a role in the pathogenesis, but antibodies might not be enough for virus neutralization [27]. A particular subpopulation of B cells, called B-1a cells, is associated with decreased serum IgM and IgD levels [28]. Some studies suggest that even when the counts of B-1a cells are lower in COVID19 patients, they produce molecules that are important for innate immunity, such as IL-10, which could block the cytokine storm [29, 30].

In general, it seems that SARS-CoV-2 can exert an exacerbated innate response causing innate cell activation and uncontrolled inflammation, which could lead to an ineffective adaptive response [31].

\section{Estradiol, the immune system, and COVID-19}

Broadly speaking, estradiol ensures excellent hydration of the mouth by increasing the production of hyaluronic acid, which affects the bronchial epithelial cells and improves the function of the lower respiratory tract by increasing antiviral molecules. Trials reported that estrogens have a strong impact on the nose and the upper respiratory tract, improving the immune response locally. One of the mechanisms involved in the protective effects of estradiol is the increases in production of nasal mucus that contains mucins, electrolytes, IgA and IgG, lysozyme, lactoferrin, and oligosaccharides. These components are known to have antiviral and antibacterial properties which would bring into play fundamental mechanisms of action to counteract upper respiratory tract infections [32].

The entry of SARS-CoV-2 is highly regulated by S protein, whose function is to mediate binding to ACE-2 in the amino-terminal region and fusion of the viral and cellular membranes in the carboxyl-terminal region. Studies have revealed that interaction between the S protein of SARSCoV-2 and the ACE2-binding site is crucial for infection and viral replication [33]. The fusion of membranes relies on the action of other proteases, particularly the transmembrane protease serine 2 (TMPRSS2). This protease is present on the host cell surface and cleaves after binding ACE2. The cellular tropism of SARS-CoV-2 is regulated by the expression of cellular proteases and ACE2 [34].

Even though the precise mechanism underlying the differential patterns of infection in men and women is yet to be elucidated, current research has strongly indicated that ACE2 expression is modulated by estradiol. Bronchial epithelial cells treated with estradiol expressed lower ACE2 mRNA levels compared to control cells [35]. This fact is important because the expression of ACE2 has been correlated with viral replication and disease severity, playing a determinant role in it [34]. However, TMPRSS2 mRNA expression was not affected by estradiol stimulus in these cells.

Estrogens can also trigger the local immune response by activating a plethora of cells such as phagocytes, dendritic cells, natural killers, and $\mathrm{CD} 8^{+} \mathrm{T}$ cells. Once these cells are activated, they can fight the infection by destroying the virus and thus preventing its diffusion to the lower respiratory tract or by decreasing the viral load [32].

Many innate and adaptive immunity components are essential for viral infections. Cells and molecules of the immune system play several roles in the mechanisms that support viral clearance [36-38]. Because hormones modulate the immune system, it is crucial to seek to clarify how this modulation may be involved in COVID-19 infections.

Estradiol modulates the immune cells which could play an essential role in explaining why a lower incidence of COVID-19 is observed among women than in men. According to Global Health 50/50, the number of men and women who tested positive for COVID-19 is almost the same. However, the vast majority of the patients with severe symptomatology belong to the male gender, which appears to strongly indicate that female hormones may have a protective role in the pathophysiology of COVID-19 [4].

Some reports show that estradiol induces inflammation, whereas others propose the opposite. Meanwhile, other studies have reported that estradiol participates in antiinflammation by downregulating MCP-1, decreasing leukocyte adhesion and migration, and inhibiting NF- $\mathrm{KB}$ macrophage activation through miR-125b [39]; the latter is thought to reduce macrophage proinflammatory cytokine release [40]. A decrease in the inflammatory reaction leads to a delay in neutrophil apoptosis and increases the expression of annexin-1 in neutrophils without increasing its activation [41].

However, most of the findings in the literature describe the immunoenhancing effects of estradiol on the immune system. Monocytes, macrophages, and neutrophils are activated by estradiol, which induces the production of proinflammatory cytokines. This in turn leads to the activation of lymphocytes and alveolar macrophages, which increases the production of type I IFN. It has been proposed that the latter actions contribute to activating antiviral responses [36].

Interferons are essentially molecules involved in viral cycle interference. Estradiol receptor $\alpha$ has been proven to have a positive mutual regulation with IFN- $\alpha$ and $-\gamma$ [37]. Since type I IFN is so important in terms of antiviral responses, this outcome is significant because estradiol might deregulate viral replication in COVID-19 infection 
through ER $\alpha$. A study conducted in mice showed that IFN- $\beta$ levels remained constant throughout the infection. However, proinflammatory cytokines and chemokines (such as IL-6, CCL-2, and CXCL-1) increased after males had been challenged with SARS-CoV2, but not in the case of females [42]. IFN- $\alpha$ has been proven to help dendritic cell maturation, activate humoral immunity, increase antibody production, and generate switch class change [43].

The antiviral role of IFNs might be outperformed by the production of autoantibodies directed against them. A study showed that 101 of 987 patients with life-threatening COVID-19 presented IFN-autoantibodies: this phenomenon is overrepresented in men and increases with age [44]. More studies need to be conducted in order to understand the relationship between hormones and IFN-autoantibody production.

Estradiol is also known to polarize the Th2 profile by modulating the function of $\mathrm{B}$ cells. The fact that females are more likely to produce higher $\mathrm{Th} 2$ responses is a doubleedged-sword since, while they become less susceptible to infections, it also makes them prone to developing autoimmune diseases [45]. In this regard, women have higher immune reactivity after viral infections, which may translate to higher serum antibody concentrations after vaccination, thereby yielding better protection [45]. Studies show that adult women can produce more neutralizing antibodies in viral infections, such as influenza, and have higher IgG production [46]. As for COVID-19 cases, a large majority of women react immunologically better and might neutralize the virus earlier than men. The discrepancy in SARS-CoV-2 antibody levels in male and female patients could potentially be a leading cause of the different outcomes of the disease [47].

The importance of estradiol in humoral immunity has been highlighted in some experiments showing that hormone replacement therapy (with estrogen) in menopausal women is associated with higher circulating B cells and modulation of inflammatory cytokines [48]. Estradiol can magnify the activation of IFN- $\alpha$ in B cells. TLRs are essential for the recognition of pathogens. In particular, B cells in females express more TLR-7 than those in males, which were increased by IFN type I [49]. Because estradiol promotes IFN type I production, it may indirectly regulate the expression of TLR7 in B lymphocytes, thus increasing the recognition of SARS-CoV-2 by these cells.

Dendritic cells are also influenced by estradiol. During inflammation, estradiol increases the number of DCs in an ER $\alpha$-dependent manner [50]. Plasmacytoid DCs are well known for their involvement in antiviral responses. They express TLR9, which is vital in detecting viral particles that produce up to $100-1000$ times more IFN- $\alpha$ than other blood cells after viral infections [51]. In this context, estradiol increases the production of IFN- $\alpha$ and the expression of costimulatory molecules [33]. It has been reported that dendritic cells are a key component for disease outcomes in several infections. Not only are they able to carry antigen presentation to $\mathrm{T}$ cells, but they also modulate their responses, leading to Th polarization and priming of naïve $\mathrm{T}$ cells [52]. Because dendritic cells play important roles in the immune response, the increase of dendritic cells in COVID-19 is a determinant of disease outcome.

Another vital cell of the immune system is the NK cell. These cells are critical for the control of certain viral infections [53], and are altered in COVID-19 patients, in whom they are affected by estrogens that exacerbate disease progression [13].

In murine models, estrogens decreased NK cytotoxicity in a dose-dependent manner [54]. This effect could be attributed to a decrease in the markers NKp46, CD69, 2B4, FasL, and granzyme B, STAT4, Fyn, Eat2, and irf1 [55]. The concentration of estradiol plays a vital role in cytotoxicity. Roszkowski et al. observed that cytotoxicity increased with concentrations $<50 \mathrm{pg} / \mathrm{mL}$ in women with mastopathy, while cytotoxicity with $>200 \mathrm{pg} / \mathrm{mL}$ was decreased [56].

In humans, NK cells are reported to change throughout the normal menstrual cycle. In the follicular phase, cytotoxicity is higher than in the luteal phase, post-menopausal women, or even men [57]. However, Yovel et al. demonstrated that the NK cells of men show higher cytotoxicity than those of women with regular menstrual cycles or women with oral contraceptives [58].

The different concentrations of the hormone might explain anti-inflammatory or activation profiles induced by estradiol. As in the case of cytokines and certain other hormones, the effects are directly related to the concentration, which is why some studies report opposite results regarding similar stimuli.

Finally, cytotoxic $\mathrm{CD} 8^{+} \mathrm{T}$ lymphocytes are essential cells in the immune response against intracellular pathogens because they can destroy virus-infected cells. In this context, estradiol may increase the activity of the virus-specific $\mathrm{CD}^{+}$cells. Robinson et al. evaluated the effect of estradiol in an influenza virus model. They observed that estradiol has a protective effect by increasing the virus-specific $\mathrm{CD} 8^{+}$ lymphocytes and augmenting the proportion of IFN- $\gamma$ and TNF- $\alpha$-producing CD $8^{+}$T cells [38] (Table 1 and Fig. 1 ).

It has been reported that the reduction of $\mathrm{CD}^{+}$and $\mathrm{CD}^{+} \mathrm{T}$ cells is a prognostic factor associated with death in COVID-19 patients, and this reduction has been particularly evident in severe COVID-19 patients compared to those who presented mild symptoms [59].

Unfortunately, to date, little information is available about the specific effect that COVID-19 exerts on every cell type. Hopefully, further information will be published in the near future, leading to a better understanding of the effect of estradiol on this disease. Nevertheless, 
Table 1 Effects of $17 \beta$-estradiol on different anatomic sites and cells

\begin{tabular}{llll}
\hline Anatomic site/cell & Effect caused by $17 \beta$-estradiol & Type of study & Reference \\
\hline Nose & Increases the production of nasal mucus & Clinical & 32 \\
Bronchial epithelial cells & Enhances the expression of ACE-2 & Experimental & 34 \\
Phagocytes & Induction of proinflammatory cytokines & Experimental & 42 \\
B cells & Increases circulating B cells & Clinical & 48 \\
& Th2 polarization & Experimental & 52 \\
Dendritic cells & Induces IFN- $\alpha$ and IFN- $\gamma$ & Experimental & 33 \\
& Induces co-stimulatory molecules & Experimental & 33 \\
NK cells & Effect dose-dependent & Clinical & 56 \\
& $<50$ pg/mL increased cytotoxicity & Clinical & 56 \\
& $>200$ pg/mL decreased cytotoxicity & & \\
T lymphocytes CD8 ${ }^{+}$ & Decreased in patients: prognostic factor & Clinical & 59 \\
& associated with death & Experimental & 38 \\
& Induces IFN- $\gamma$ and TNF- $\alpha$ production & & \\
& & &
\end{tabular}

Abbreviations:

$A C E$-2, angiotensin-converting enzyme 2; $N K$, natural killer; $I F N$, interferon; $T N F$, tumor necrosis factor; $p g$, picogram; $m L$, mililiter understanding the general effects estradiol has on the immune cells will help identify possible mechanisms underlying the hormone's apparent ability to provide protection to women. Taking this into account, an approach based on the known effects of estradiol for the development of a new therapy could be conceived, leading to decreasing infectivity or the severity of the disease.

\section{Dendritic cells}

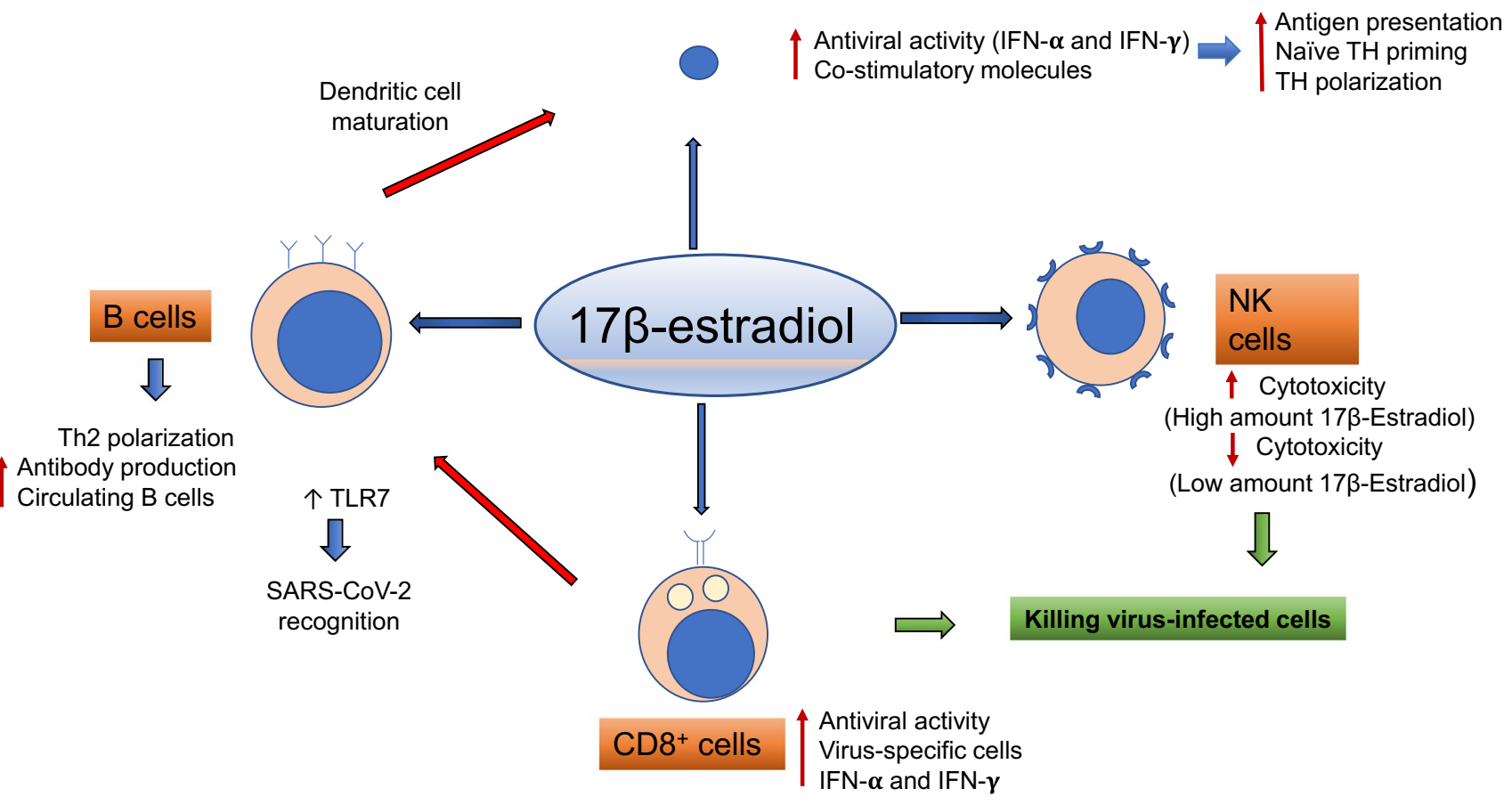

Fig. 1 Regulation of $17 \beta$-estradiol on the immune cells. $17 \beta$-estradiol has regulatory effects upon B, dendritic, NK, and CD8 ${ }^{+}$cells and induces their stimulation, leading to an antiviral state and activating the immune response 


\section{Participation of other hormones}

Other female hormones, in particular progesterone, have been shown to have a combined effect with estradiol by enhancing their actions and increasing the expression of their receptors. Indeed, during infectious diseases, increased use of hormonal contraceptives has been recommended by the WHO [60].

Progesterone has proven to increase the positive effect of estradiol by increasing the expression of the epidermal growth factor amphiregulin, which helps promote the lung repair process. Progesterone administration in menopausal women has also been shown to improve the outcome of pulmonary disease [60].

Progesterone was recently found to have an antiviral effect against SARS-CoV-2 in vitro [61]. It has been proposed that a possible mechanism of action could be the increase of BMP accumulation, which, in combination with chloroquine treatment, would lead to impairment of the endosomal/lysosomal trafficking of SARS-CoV-2 and result in the virus being sequestered in multivesicular bodies [62].

In other viral infections, such as the influenza A virus, progesterone plays a pivotal role in the repair of pulmonary tissue and alteration in inflammation by improving pulmonary function and preparing the environment for pulmonary repair, which, in combination, was shown to result in early recovery [60].

Unquestionably, more research focused on NK regulation on COVID-19 must be conducted since these cells are especially susceptible to progesterone. Mature NK CD56 ${ }^{\mathrm{dim}} \mathrm{CD} 16{ }^{+} \mathrm{KIR}^{+}$cells overexpress the progesterone receptor to an even greater degree than the $\mathrm{T}$ and $\mathrm{B}$ lymphocytes and stimulation with progesterone could lead them to apoptosis [63].

Other hormones involved in the functions of the immune system are the thyroid hormones (TH), TSH, T3, and $\mathrm{T} 4$ [64]. It has been reported that patients infected by SARS-CoV-2 present disorders in thyroid function since follicular thyroid cells express ACE2, which renders the organ susceptible to SARS-CoV-2 infection [65]. This phenomenon was first reported in 2003 during the SARS-CoV-1 outbreak. Based on the above, Khoo et al. carried out a comparison of clinical outcomes between patients with thyroid problems before and after the SARSCoV-2 infection: they observed that $86 \%$ of patients with COVID-19 had thyroid dysfunction characterized by a decrease in TSH and T4 levels compared to their levels before becoming infected with SARS-CoV-2 in contrast to negative patients [66].

On the other hand, different studies have shown a correlation in TH levels with the severity of the disease. Gao et al. demonstrated that patients who progressed to severe disease had low levels of free T3 [67]. However, Lui et al. reported that only $15 \%$ of patients with thyroid dysfunction had mild to moderate symptoms of COVID-19, which was associated with a decrease in free T3 [68].

TH imbalance due to SARS-CoV-2 may be involved in a dysfunction of the immune system: as in patients with Graves' disease, which is an autoimmune disorder associated with an impairment in the production of TH [64]. In contrast, in neutrophils, an increase in their inflammatory activity was observed. Considering the latter, it is very important to realize that some endocrine conditions might be related to COVID-19. Subacute thyroiditis, an inflammatory disorder, has been reported after SARS-CoV-2 infection. All these data are crucial for alerting clinicians to the diverse manifestations associated with COVID-19 [69].

\section{Treatment and clinical trials}

To date, no treatment has been shown to be effective against SARS-CoV-2 infection. The necessity to identify molecules that can prevent the worsening outcome observed in many patients has led some research groups to evaluate how useful certain compounds are for treatment of COVID-19. In this context, estradiol and progesterone are possible candidates, given their essential participation in reducing susceptibility to infection.

Natural components are useful in blocking the interaction between the virus and target cells by impeding the recognition site for HSPA5 and competing for the recognition of the viral spike protein. In order to identify possible compounds capable of supporting the treatment of COVID-19, many natural products were tested, among which were estrogen, phytoestrogens, and progesterone. Due to their binding affinities, they were found to be optimal for the binding the HSPA5 protein, which is necessary for the virus to be transmitted. [70].

Based on the importance of estradiol and progesterone in intracellular infections and COVID-19, trials are being conducted to more accurately evaluate their effects on the disease.

The approach adopted by phase 2 of the Stony Brook clinical trial NCT04359329 is to treat patients with an estradiol patch. Men over 18 years of age and women over 55 with a positive diagnosis of COVID-19, or presumed positive and not requiring intubation, were recruited for this trial. They will be followed up for $1,7,14$, and 28 days for clinical symptoms and clinical outcomes. It is hypothesized that the application of a transdermal patch for 7 days in COVID-19+ will reduce the severity of the symptoms when administrated before intubation [71]. 
Conversely, because progesterone has anti-inflammatory properties, which could be extremely helpful during the cytokine storm induced by SARS-CoV-2 infection, a clinical trial with this approach was conducted. Patients recruited for the Cedars-Sinai NCT04365127 phase 1 clinical trial will include hospitalized men positive for COVID-19. After being enrolled and informed about the study and its potential risks, the patients will be randomized to receive $100 \mathrm{mg}$ of progesterone twice a day [72].

\section{Clinical background}

The role of estradiol in critically ill patients was a topic of interest even before the SARS-CoV-2 pandemic. This hormone is inhibited by class I cytokines and TNF alpha during stress. However, its peripheral production by enzyme aromatase in adipose tissue is activated regardless of gender [73]. Estradiol levels were measured in critically ill patients before management in intensive care units (ICUs), and the differences were remarkable between survivors and non-survivors $(p<0.01)$ in whom the mean levels of estradiol were 62.2 versus $116 \mathrm{pg} / \mathrm{mL}$, respectively [73]. Another study from 2011 reported that high estradiol levels for ICU admission were associated with high mortality in a cohort of 1408 critically ill patients (14.1\%, 95\% CI 12.3-16). The authors concluded that estradiol level dynamics during critical stages might help in targeted therapies [74]. A prospective cohort study performed in ICU patients in 2008 reported that estradiol levels were significantly higher in non-survivors regardless of gender (40.7 versus $18.7 \mathrm{pg} / \mathrm{mL}$ ) [75]. In general terms, scientific evidence from non-SARS-CoV-2 infected patients reveals that abnormally high estradiol levels in critically ill patients are associated with poor outcomes [73-75].

However, over the past 12 months, new research has been developed related to SARS-CoV-2-infected patients. Several inflammatory markers have been used to monitor the severity and progression of infected patients. The most common are procalcitonin, serum ferritin, D-dimer, C-reactive protein, lactate dehydrogenase, and cytokines [76]. Meanwhile, the role of other biological markers has been reviewed. Mauvais-Jarvis et al. reviewed the effects of hormones regarding the outcomes of patients with SARS-CoV-2. They concluded that estradiol and progesterone might help mitigate proinflammatory responses in infected patients, and that acute estradiol treatment would be expected to blunt the cytokine storm [77]. Regarding gender, some data have shown a differentiation between the immune response based on estradiol levels. Specifically, infected SARS-CoV-2 males have a higher risk of mortality (RR, 1.4; 95\% CI, 1.2-1.7) due to estradiol-deprived monocytes and monocyte-derived macrophages. The effect induces higher levels of CD16 as well as increases in IL-6, TNF alpha, and IL-1ß [76].
Experimental tests have reported that estradiol can affect ACE2 and FURIN expression, with the potential of mitigating SARS-CoV-2 infection in combination with other compounds [78]. Other authors have reported potential positive effects of estradiol against SARS-CoV-2 infection as an adjuvant therapeutic option $[79,80]$.

The role of estradiol and other compounds for the management of SARS-CoV-2 is still on the table, and, although the amount of scientific information is on the increase, it is as yet scarce and lacks clinical trials. For the moment, clinicians need to bear in mind that we are dealing with a great challenge and, as such, must ensure optimal medical care based on internationally accepted protocols.

\section{Conclusion}

Infection with SARS-CoV-2 leads to COVID-19, which presents in several forms, including asymptomatic, mild, or severe, and can even lead to death. Even though the mechanism of infection has been described, many questions still remain as to the outcome of the disease. Estradiol seems to be important in reducing the severity of the disease and the intensity of the symptoms; however, its mechanism in the context of COVID-19 is not so far well understood. Estradiol has been proven to be involved in modulating immune cells in several models, these effects elucidating its action to some degree. Some of the actions that estradiol performs are activation of B cells and production of neutralizing antibodies, augmentation of dendritic cells, increase in NK cytotoxicity at low concentrations, and an increase in the virus-specific $\mathrm{CD} 8^{+}$lymphocytes.

Because estradiol is involved in reducing susceptibility to COVID-19 as well as its severity, research is focused on utilizing it as a therapeutic target.

Author contribution Adrián Ramírez-de-Arellano, Jorge GutiérrezFranco, and Ana Laura Pereira-Suárez participated equally in the writing and review of the article. Erick Sierra-Díaz participated in the writing of "the clinical ground" section.

\section{Declarations}

Ethics approval Not applicable.

Consent to participate.

Not applicable.

Consent for publication. The corresponding author transfers to Springer the non-exclusive publication rights and she warrants that her contribution is original and that she has full power to make this grant. The corresponding author signs for and accepts responsibility for releasing this material on behalf of any and all co-authors. This transfer of publication rights covers the non-exclusive right to reproduce and distribute the article, including reprints, translations, photographic 
reproductions, microform, electronic form (offline, online), or any other reproductions of a similar nature.

Conflict of interest The authors declare no competing interests.

\section{References}

1. Lu R, Zhao X, Li J, Niu P, Yang B, Wu H, Wang W, Song H, Huang B, Zhu N, Bi Y, Ma X, Zhan F, Wang L, Hu T, Zhou H, Hu Z, Zhou W, Zhao L, Chen J, Meng Y, Wang J, Lin Y, Yuan J, Xie Z, Ma J, Liu WJ, Wang D, Xu W, Holmes EC, Gao GF, Wu G, Chen W, Shi W, Tan W (2020) Genomic characterisation and epidemiology of 2019 novel coronavirus: implications for virus origins and receptor binding. Lancet 395:565-574. https://doi.org/ 10.1016/S0140-6736(20)30251-8

2. Yuki K et al (2020) Review article COVID-19 pathophysiology: a review. Clin Immunol 215:1-8

3. Zhou M, Zhang X, Qu J (2020) Coronavirus disease 2019 (COVID-19): a clinical update. Front Med 14:126-135. https:// doi.org/10.1007/s11684-020-0767-8

4. Global Health 5050. (2020) The COVID-19 sex-disaggregated data tracker. https://globalhealth5050.org/the-sex-gender-andcovid-19-project/. Accessed 28 Jan 2021

5. Chen H, Guo J, Wang C, Luo F, Yu X, Zhang W, Li J, Zhao D, Xu D, Gong Q, Liao J, Yang H, Hou W, Zhang Y (2020) Clinical characteristics and intrauterine vertical transmission potential of COVID-19 infection in nine pregnant women: a retrospective review of medical records. Lancet 395:809-815. https://doi.org/ 10.1016/S0140-6736(20)30360-3

6. Dana PM, Kolahdooz F, Sadoughi F, Moazzami B, Chaichian S, Asemi Z (2020) COVID-19 and pregnancy: a review of current knowledge. Infez Med 28:46-51

7. Rizzo P, Vieceli Dalla Sega F, Fortini F, Marracino L, Rapezzi C, Ferrari R (2020) COVID-19 in the heart and the lungs: could we "Notch" the inflammatory storm? Basic Res Cardiol 115:31. https://doi.org/10.1007/s00395-020-0791-5

8. Okba NMA, Müller MA, Li W, Wang C, GeurtsvanKessel CH, Corman VM, Lamers MM, Sikkema RS, de Bruin E, Chandler FD, Yazdanpanah Y, Le Hingrat Q, Descamps D, Houhou-Fidouh N, Reusken CBEM, Bosch B-J, Drosten C, Koopmans MPG, Haagmans BL (2020) Severe acute respiratory syndrome coronavirus $2-$ specific antibody responses in coronavirus disease patients. Emerg Infect Dis 26:1478-1488. https://doi.org/10.3201/eid2607. 200841

9. Zhao J, Yuan Q, Wang H, Liu W, Liao X, Su Y, Wang X, Yuan J, Li T, Li J, Qian S, Hong C, Wang F, Liu Y, Wang Z, He Q, Li Z, He B, Zhang T, Fu Y, Ge S, Liu L, Zhang J, Xia N, Zhang Z (2020) Antibody responses to SARS-CoV-2 in patients with novel coronavirus disease 2019. Clin Infect Dis 71:2027-2034. https:// doi.org/10.1093/cid/ciaa344

10. Liu J, Li S, Liu J, Liang B, Wang X, Wang H, Li W, Tong Q, Yi J, Zhao L, Xiong L, Guo C, Tian J, Luo J, Yao J, Pang R, Shen H, Peng C, Liu T, Zhang Q, Wu J, Xu L, Lu S, Wang B, Weng Z, Han C, Zhu H, Zhou R, Zhou H, Chen X, Ye P, Zhu B, Wang L, Zhou W, He S, He Y, Jie S, Wei P, Zhang J, Lu Y, Wang W, Zhang L, Li L, Zhou F, Wang J, Dittmer U, Lu M, Hu Y, Yang D, Zheng X (2020) Longitudinal characteristics of lymphocyte responses and cytokine profiles in the peripheral blood of SARSCoV-2 infected patients. EBioMedicine 55:102763. https://doi. org/10.1016/j.ebiom.2020.102763

11. Park MD (2020) Macrophages: a Trojan horse in COVID19? Nat Rev Immunol 20:351-351. https://doi.org/10.1038/ s41577-020-0317-2
12. López-Collazo E, del Fresno C (2013) Pathophysiology of endotoxin tolerance: mechanisms and clinical consequences. Crit Care 17:242. https://doi.org/10.1186/cc13110

13. Zheng M, Gao Y, Wang G, Song G, Liu S, Sun D, Xu Y, Tian Z (2020) Functional exhaustion of antiviral lymphocytes in COVID19 patients. Cell Mol Immunol 17:533-535. https://doi.org/10. 1038/s41423-020-0402-2

14. Lee C-H, Chen R-F, Liu J-W, Yeh W-T, Chang J-C, Liu P-M, Eng H-L, Lin M-C, Yang KD (2004) Altered p38 mitogen-activated protein kinase expression in different leukocytes with increment of immunosuppressive mediators in patients with severe acute respiratory syndrome. J Immunol 172:7841-7847. https://doi.org/ 10.4049/jimmunol.172.12.7841

15. Gleason MK, Lenvik TR, McCullar V, Felices M, O'Brien MS, Cooley SA, Verneris MR, Cichocki F, Holman CJ, Panoskaltsis-Mortari A, Niki T, Hirashima M, Blazar BR, Miller JS (2012) Tim-3 is an inducible human natural killer cell receptor that enhances interferon gamma production in response to galectin-9. Blood 119:3064-3072. https://doi.org/10.1182/ blood-2011-06-360321

16. Costela-Ruiz VJ, Illescas-Montes R, Puerta-Puerta JM, Ruiz C, Melguizo-Rodríguez L (2020) SARS-CoV-2 infection: the role of cytokines in COVID-19 disease. Cytokine Growth Factor Rev 54:62-75. https://doi.org/10.1016/j.cytogfr.2020.06.001

17. Sanchez-Cerrillo I, Landete P, Aldave B, Sanchez-Alonso S, Sanchez-Azofra A, Marcos-Jimenez A, Avalos E, Alcaraz-Serna A, de Los Santos I, Mateu-Albero T, Esparcia L, Lopez-Sanz C, Martinez-Fleta P, Gabrie L, Del Campo Guerola L, Calzada MJ, Gonzalez-Alvaro I, Alfranca A, Sanchez-Madrid F, MunozCalleja C, Soriano JB, Ancochea J, Martin-Gayo E (2020) Differential redistribution of activated monocyte and dendritic cell subsets to the lung associates with severity of COVID-19. medRxiv Prepr Serv Heal Sci. https://doi.org/10.1101/2020.05.13.20100 925

18. Zhou R, To KK-W, Wong Y-C, Liu L, Zhou B, Li X, Huang H, Mo Y, Luk T-Y, Lau TT-K, Yeung P, Chan W-M, Wu AK-L, Lung K-C, Tsang OT-Y, Leung W-S, Hung IF-N, Yuen K-Y, Chen Z (2020) Acute SARS-CoV-2 infection impairs dendritic cell and T cell responses. Immunity 53:864-877.e5. https://doi.org/10.1016/j. immuni.2020.07.026

19. Law HKW, Cheung CY, Ng HY, Sia SF, Chan YO, Luk W, Nicholls JM, Peiris JSM, Lau YL (2005) Chemokine up-regulation in SARS-coronavirus-infected, monocyte-derived human dendritic cells. Blood 106:2366-2374. https://doi.org/10.1182/ blood-2004-10-4166

20. Huang C, Wang Y, Li X, Ren L, Zhao J, Hu Y, Zhang L, Fan G, Xu J, Gu X, Cheng Z, Yu T, Xia J, Wei Y, Wu W, Xie X, Yin W, Li H, Liu M, Xiao Y, Gao H, Guo L, Xie J, Wang G, Jiang R, Gao Z, Jin Q, Wang J, Cao B (2020) Clinical features of patients infected with 2019 novel coronavirus in Wuhan, China. Lancet 395:497-506. https://doi.org/10.1016/S0140-6736(20)30183-5

21. Qin C, Zhou L, Hu Z, Zhang S, Yang S, Tao Y, Xie C, Ma K, Shang K, Wang W, Tian D-S (2020) Dysregulation of immune response in patients with coronavirus 2019 (COVID-19) in Wuhan, China. Clin Infect Dis 71:762-768. https://doi.org/10. 1093/cid/ciaa248

22. Okabayashi T, Kariwa H, Yokota S, Iki S, Indoh T, Yokosawa N, Takashima I, Tsutsumi H, Fujii N (2006) Cytokine regulation in SARS coronavirus infection compared to other respiratory virus infections. J Med Virol 78:417-424. https://doi.org/10.1002/jmv. 20556

23. Russell B, Moss C, George G, Santaolalla A, Cope A, Papa S, Van Hemelrijck M (2020) Associations between immune-suppressive and stimulating drugs and novel COVID-19-a systematic review of current evidence. Ecancermedicalscience 14: . https://doi.org/ 10.3332/ecancer.2020.1022 
24. Cao X (2020) COVID-19: immunopathology and its implications for therapy. Nat Rev Immunol 20:269-270. https://doi.org/ 10.1038/s41577-020-0308-3

25. Moon C (2020) Fighting COVID-19 exhausts T cells. Nat Rev Immunol 20:277-277. https://doi.org/10.1038/s41577-020-0304-7

26. Thevarajan I, Nguyen THO, Koutsakos M, Druce J, Caly L, van de Sandt CE, Jia X, Nicholson S, Catton M, Cowie B, Tong SYC, Lewin SR, Kedzierska K (2020) Breadth of concomitant immune responses prior to patient recovery: a case report of nonsevere COVID-19. Nat Med 26:453-455. https://doi.org/10.1038/ s41591-020-0819-2

27. Guo L, Ren L, Yang S, Xiao M, Chang D, Yang F, Dela Cruz CS, Wang Y, Wu C, Xiao Y, Zhang L, Han L, Dang S, Xu Y, Yang Q-W, Xu S-Y, Zhu H-D, Xu Y-C, Jin Q, Sharma L, Wang L, Wang J (2020) Profiling early humoral response to diagnose novel coronavirus disease (COVID-19). Clin Infect Dis 71:778-785. https:// doi.org/10.1093/cid/ciaa310

28. Wen W, Su W, Tang H, Le W, Zhang X, Zheng Y, Liu X, Xie L, Li J, Ye J, Dong L, Cui X, Miao Y, Wang D, Dong J, Xiao C, Chen W, Wang H (2020) Immune cell profiling of COVID-19 patients in the recovery stage by single-cell sequencing. Cell Discov 6: . https://doi.org/10.1038/s41421-020-0168-9

29. Aziz M, Holodick NE, Rothstein TL, Wang P (2015) The role of B-1 cells in inflammation. Immunol Res 63:153-166. https://doi. org/10.1007/s12026-015-8708-3

30. Fereidan-Esfahani M, Nayfeh T, Warrington A, Howe CL, Rodriguez M (2019) IgM natural autoantibodies in physiology and the treatment of disease. pp 53-81

31. López-Collazo E, Avendaño-Ortiz J, Martín-Quirós A, Aguirre LA (2020) Immune response and COVID-19: a mirror image of Sepsis. Int J Biol Sci 16:2479-2489. https://doi.org/10.7150/ijbs. 48400

32. Di Stadio A, M. R, G. R, (2020) Gender differences in COVID-19 infection. The estrogen effect on upper and lower airways. Can it help to figure out a treatment? Eur Rev Med Pharmacol Sci 24:5195-5196

33. Li W, Zhang C, Sui J, Kuhn JH, Moore MJ, Luo S, Wong SK, Huang IC, Xu K, Vasilieva N, Murakami A, He Y, Marasco WA, Guan Y, Choe H, Farzan M (2005) Receptor and viral determinants of SARS-coronavirus adaptation to human ACE2. EMBO J 24:1634-1643. https://doi.org/10.1038/sj.emboj.7600640

34. Hoffmann M, Kleine-Weber H, Schroeder S, Krüger N, Herrler T, Erichsen S, Schiergens TS, Herrler G, Wu NH, Nitsche A, Müller MA, Drosten C, Pöhlmann S (2020) SARS-CoV-2 cell entry depends on ACE2 and TMPRSS2 and is blocked by a clinically proven protease inhibitor. Cell 181:271-280.e8. https://doi.org/10. 1016/j.cell.2020.02.052

35. Stelzig KE, Canepa-Escaro F, Schiliro M, Berdnikovs S, Prakash YS, Chiarella SE (2020) Estrogen regulates the expression of SARS-CoV-2 receptor ACE2 in differentiated airway epithelial cells. Am J Physiol Cell Mol Physiol 318:L1280-L1281. https:// doi.org/10.1152/ajplung.00153.2020

36. Kovats S (2015) Estrogen receptors regulate innate immune cells and signaling pathways. Cell Immunol 294:63-69. https://doi.org/ 10.1016/j.cellimm.2015.01.018

37. Panchanathan R, Shen H, Zhang X, mei Ho S, Choubey D (2010) Mutually positive regulatory feedback loop between interferons and estrogen receptor- $\$ \alpha \$$ in mice: implications for sex bias in autoimmunity. PLoS One 5: . https://doi.org/10.1371/journal. pone. 0010868

38. Robinson DP, Hall OJ, Nilles TL, Bream JH, Klein SL (2014) 17 -estradiol protects females against influenza by recruiting neutrophils and increasing virus-specific CD8 T cell responses in the lungs. J Virol 88:4711-4720. https://doi.org/10.1128/jvi.02081-13
39. Murphy AJ, Guyre PM, Pioli PA (2010) Estradiol suppresses $N F-\kappa B$ activation through coordinated regulation of let-7a and miR-125b in primary human macrophages. J Immunol 184:5029-5037. https://doi.org/10.4049/jimmunol.0903463

40. Kramer PR, Winger V, Kramer SF (2007) 17 $\beta$-Estradiol utilizes the estrogen receptor to regulate CD16 expression in monocytes. Mol Cell Endocrinol 279:16-25. https://doi.org/10. 1016/j.mce.2007.08.014

41. Nadkarni S, Cooper D, Brancaleone V, Bena S, Perretti M (2011) Activation of the annexin A1 pathway underlies the protective effects exerted by estrogen in polymorphonuclear leukocytes. Arterioscler Thromb Vasc Biol 31:2749-2759. https:// doi.org/10.1161/ATVBAHA.111.235176

42. Channappanavar R, Fett C, Mack M, Ten EPP, Meyerholz DK, Perlman S (2018) Sex-based differences in susceptibility to SARS-CoV infection. J Immunol 198:319-335. https://doi.org/ 10.4049/jimmunol.1601896.Sex-based

43. Le Bon A, Schiavoni G, D’Agostino G, Gresser I, Belardelli F, Tough DF (2001) Type I interferons potently enhance humoral immunity and can promote isotype switching by stimulating dendritic cells in vivo. Immunity 14:461-470. https://doi.org/ 10.1016/S1074-7613(01)00126-1

44. Bastard P, Rosen LB, Zhang Q, Zhang Y, Dorgham K, Béziat V, Puel A, Lorenzo L, Bizien L, Assant S, Fillipot Q, Seeleuthner Y, Hadjadj J, Bigio B, Michael S, Shaw E, Chauvin SD, Belot A, Rieux-laucat F (2020) IgG autoantibodies against type I IFNs in patients with severe COVID-19. Science (80- ) 4585:1-19

45. Cutolo M, Smith V, Paolino S (2020) Editorial: understanding immune effects of oestrogens to explain the reduced morbidity and mortality in female versus male COVID-19 patients. Comparisons with autoimmunity and vaccination. Clin Exp Rheumatol 38:383-386

46. Furman D, Hejblum BP, Simon N, Jojic V, Dekker CL, Thiebaut R, Tibshirani RJ, Davis MM (2014) Systems analysis of sex differences reveals an immunosuppressive role for testosterone in the response to influenza vaccination. Proc Natl Acad Sci U S A 111:869-874. https://doi.org/10.1073/pnas.1321060111

47. Zeng F, Dai C, Cai P, Wang J, Xu L, Li J, Hu G, Wang Z, Zheng F, Wang L (2020) A comparison study of SARS-CoV-2 IgG antibody between male and female COVID-19 patients: a possible reason underlying different outcome between sex. J Med Virol 92:2050-2054. https://doi.org/10.1002/jmv.25989

48. Kamada M, Irahara M, Maegawa M, Yasui T, Yamano S, Yamada M, Tezuka M, Kasai Y, Deguchi K, Ohmoto Y, Aono T (2001) B cell subsets in postmenopausal women and the effect of hormone replacement therapy. Maturitas 37:173-179. https:// doi.org/10.1016/S0378-5122(00)00180-8

49. Dong G, Fan H, Yang Y, Zhao G, You M, Wang T, Hou Y (2015) 17 $\beta$-Estradiol enhances the activation of IFN- $\alpha$ signaling in B cells by down-regulating the expression of let-7e-5p, miR-98-5p and miR-145a-5p that target IKKe. Biochim Biophys Acta - Mol Basis Dis 1852:1585-1598. https://doi.org/10. 1016/j.bbadis.2015.04.019

50. Kovats S (2012) Estrogen receptors regulate an inflammatory pathway of dendritic cell differentiation: mechanisms and implications for immunity. Horm Behav 62:254-262. https://doi.org/ 10.1016/j.yhbeh.2012.04.011

51. Cella M, Jarrossay D, Faccheth F, Alebardi O, Nakajima H, Lanzavecchia A, Colonna M (1999) Plasmacytoid monocytes migrate to inflamed lymph nodes and produce large amounts of type I interferon. Nat Med 5:919-923. https://doi.org/10.1038/ 11360

52. Freer G, Matteucci D (2009) Influence of dendritic cells on viral pathogenicity. PLoS Pathog 5: . https://doi.org/10.1371/journal. ppat.1000384 
53. Biron CA, Byron KS, L. SJ, (1989) Severe herpesvirus infections in an adolescent without natural killer cells. Med Intel 320:1731-1735

54. Nilsson N, Carlsten H (1994) Estrogen induces suppression of natural killer cell cytotoxicity and augmentation of polyclonal B cell activation. Cell Immunol 158:131-139

55. Hao S, Li P, Zhao J, Hu Y, Hou Y (2008) 17\$ \$\$-estradiol suppresses cytotoxicity and proliferative capacity of murine splenic NK1.1+ cells. Cell Mol Immunol 5:357-364. https://doi.org/10. 1038/cmi.2008.44

56. Roszkowski PI, Hyc A, Stopińska-Głuszak U, Malejczyk J (1997) Natural killer cell activity and sex hormone levels in mastopathy. Gynecol Endocrinol 11:399-404. https://doi.org/10.3109/09513599709152567

57. Souza SS, Castro FA, Mendonça HC, Palma PVB, Morais FR, Ferriani RA, Voltarelli JC (2001) Influence of menstrual cycle on NK activity. J Reprod Immunol 50:151-159. https://doi.org/ 10.1016/S0165-0378(00)00091-7

58. Yovel G, Shakhar K, Ben-Eliyahu S (2001) The effects of sex, menstrual cycle, and oral contraceptives on the number and activity of natural killer cells. Gynecol Oncol 81:254-262. https://doi. org/10.1006/gyno.2001.6153

59. Cantenys-Molina S, Fernández-Cruz E, Francos P, Lopez Bernaldo de Quirós JC, Muñoz P, Gil-Herrera J (2020) Lymphocyte subsets early predict mortality in a large series of hospitalized COVID-19 patients in Spain. Clin Exp Immunol 1-9 . https://doi. org/10.1111/cei.13547

60. Hall OJ, Limjunyawong N, Vermillion MS, Robinson DP, Wohlgemuth N, Pekosz A, Mitzner W, Klein SL (2016) Progesteronebased therapy protects against influenza by promoting lung repair and recovery in females. PLoS Pathog 12:1-22. https://doi.org/10. 1371/journal.ppat. 1005840

61. Gordon DE, Jang GM, Bouhaddou M, Xu J, Obernier K, White KM, O’Meara MJ, Rezelj VV, Guo JZ, Swaney DL, Tummino TA, Hüttenhain R, Kaake RM, Richards AL, Tutuncuoglu B, Foussard H, Batra J, Haas K, Modak M, Kim M, Haas P, Polacco BJ, Braberg H, Fabius JM, Eckhardt M, Soucheray M, Bennett MJ, Cakir M, McGregor MJ, Li Q, Meyer B, Roesch F, Vallet T, Mac Kain A, Miorin L, Moreno E, Naing ZZC, Zhou Y, Peng S, Shi Y, Zhang Z, Shen W, Kirby IT, Melnyk JE, Chorba JS, Lou K, Dai SA, Barrio-Hernandez I, Memon D, Hernandez-Armenta C, Lyu J, Mathy CJP, Perica T, Pilla KB, Ganesan SJ, Saltzberg DJ, Rakesh R, Liu X, Rosenthal SB, Calviello L, Venkataramanan S, Liboy-Lugo J, Lin Y, Huang XP, Liu YF, Wankowicz SA, Bohn M, Safari M, Ugur FS, Koh C, Savar NS, Tran QD, Shengjuler D, Fletcher SJ, O’Neal MC, Cai Y, Chang JCJ, Broadhurst DJ, Klippsten S, Sharp PP, Wenzell NA, Kuzuoglu-Ozturk D, Wang HY, Trenker R, Young JM, Cavero DA, Hiatt J, Roth TL, Rathore U, Subramanian A, Noack J, Hubert M, Stroud RM, Frankel AD, Rosenberg OS, Verba KA, Agard DA, Ott M, Emerman M, Jura N, von Zastrow M, Verdin E, Ashworth A, Schwartz O, d'Enfert C, Mukherjee S, Jacobson M, Malik HS, Fujimori DG, Ideker T, Craik CS, Floor SN, Fraser JS, Gross JD, Sali A, Roth BL, Ruggero D, Taunton J, Kortemme T, Beltrao P, Vignuzzi M, García-Sastre A, Shokat KM, Shoichet BK, Krogan NJ (2020) A SARS-CoV-2 protein interaction map reveals targets for drug repurposing. Nature 583:459-468. https://doi. org/10.1038/s41586-020-2286-9

62. Carrière F, Longhi S, Record M (2020) The endosomal lipid bis(monoacylglycero) phosphate as a potential key player in the mechanism of action of chloroquine against SARS-COV-2 and other enveloped viruses hijacking the endocytic pathway.
Biochimie 179:237-246. https://doi.org/10.1016/j.biochi.2020. 05.013

63. Arruvito L, Giulianelli S, Flores AC, Paladino N, Barboza M, Lanari C, Fainboim L (2008) NK cells expressing a progesterone receptor are susceptible to progesterone-induced apoptosis. J Immunol 180:5746-5753. https://doi.org/10.4049/jimmunol. 180.8.5746

64. Del Mar MM, Pellizas C (2019) Thyroid hormone action on innate immunity. Front Endocrinol (Lausanne) 10:1-9. https://doi.org/ 10.3389/fendo.2019.00350

65. Giovanella L, Ruggeri RM, Ovčariček PP, Campenni A, Treglia G, Deandreis D (2021) Prevalence of thyroid dysfunction in patients with COVID-19: a systematic review. Clin Transl Imaging. https://doi.org/10.1007/s40336-021-00419-y

66. Khoo B, Tan T, Clarke SA, Mills EG, Patel B, Modi M, Phylactou M, Eng PC, Thurston L, Alexander EC, Meeran K, Comninos AN, Abbara A, Dhillo WS (2021) Thyroid function before, during, and after COVID-19. J Clin Endocrinol Metab 106:e803-e811. https:// doi.org/10.1210/clinem/dgaa830

67. Gao W, Guo W, Guo Y, Shi M, Dong G, Wang G, Ge Q, Zhu J, Zhou X (2020) Thyroid hormone concentrations in severely or critically ill patients with COVID-19. J Endocrinol Invest. https:// doi.org/10.1007/s40618-020-01460-w

68. Lui DTW, Lee CH, Chow WS, Lee ACH, Tam AR, Fong CHY, Law CY, Leung EKH, To KKW, Tan KCB, Woo YC, Lam CW, Hung IFN, Lam KSL (2021) Thyroid dysfunction in relation to immune profile, disease status, and outcome in 191 patients with COVID-19. J Clin Endocrinol Metab 106:e926-e935. https://doi. org/10.1210/clinem/dgaa813

69. Ruggeri RM, Campennì A, Siracusa M, Frazzetto G, Gullo D (2021) Subacute thyroiditis in a patient infected with SARSCOV-2: an endocrine complication linked to the COVID-19 pandemic. Hormones 20:219-221. https://doi.org/10.1007/ s42000-020-00230-w

70. Elfiky AA (2020) Natural products may interfere with SARSCoV-2 attachment to the host cell. J Biomol Struct Dyn 0:1-16. https://doi.org/10.1080/07391102.2020.1761881

71. NIH (2020) Estrogen patch for COVID-19 symptoms. In: Clin. trials.gov. https://www.clinicaltrials.gov/ct2/show/NCT04359329. Accessed 30 Dec 2020

72. NIH (2020) Progesterone for the treatment of COVID-19 in hospitalized men. In: Clin. trials.gov. https://www.clinicaltrials.gov/ ct2/show/NCT04365127. Accessed 30 Dec 2020

73. Sanchez-Hurtado LA, Lugo-Cob R, Tejeda-Huezo BC, EsquivelChávez A, Cano-Oviedo AA, Zamora-Varela S, Gomez-Flores SS, Arvizu-Tachiquin P, Baltazar-Torres JA (2018) Serum estradiol level at intensive care unit admission and mortality in critically ill patients. Indian J Crit Care Med 22:96-99. https://doi.org/10. 4103/ijccm.IJCCM_395_16

74. Kauffmann RM, Norris PR, Jenkins JM, Dupont WD, Torres RE, Blume JD, Dossett LA, Hranjec T, Sawyer RG, May AK (2011) Trends in estradiol during critical illness are associated with mortality independent of admission estradiol. J Am Coll Surg 212:703-712. https://doi.org/10.1016/j.jamcollsurg. 2010.12.017

75. Dossett LA, Swenson BR, Evans HL, Bonatti H, Sawyer RG, May AK (2008) Serum estradiol concentration as a predictor of death in critically ill and injured adults. Surg Infect (Larchmt) 9:41-48. https://doi.org/10.1089/sur.2007.037

76. Hussman JP (2020) Cellular and molecular pathways of COVID19 and potential points of therapeutic intervention. Front Pharmacol 11: . https://doi.org/10.3389/fphar.2020.01169 
77. Mauvais-Jarvis F, Klein SL, Levin ER (2020) Estradiol, progesterone, immunomodulation, and COVID-19 outcomes. Endocrinology 161: . https://doi.org/10.1210/endocr/bqaa127

78. Glinsky GV (2020) Tripartite combination of candidate pandemic mitigation agents: vitamin $\mathrm{D}$, quercetin, and estradiol manifest properties of medicinal agents for targeted mitigation of the COVID-19 pandemic defined by genomics-guided tracing of SARS-CoV-2 targets in human. Biomedicines 8:129. https://doi. org/10.3390/biomedicines8050129

79. Breithaupt-Faloppa AC, Correia C de J, Prado CM, Stilhano RS, Ureshino RP, Moreira LFP (2020) 17 $\beta$-Estradiol, a potential ally to alleviate SARS-CoV-2 infection. Clinics 75: . https://doi.org/ 10.6061/clinics/2020/e1980

80. Grandi G, Facchinetti F, Bitzer J (2020) The gendered impact of coronavirus disease (COVID-19): do estrogens play a role? Eur J Contracept Reprod Heal Care 25:233-234. https://doi.org/10. 1080/13625187.2020.1766017

Publisher's Note Springer Nature remains neutral with regard to jurisdictional claims in published maps and institutional affiliations. 